2009

\title{
Reforming the NAFTA Investment Regime
}

Gus Van Harten

Osgoode Hall Law School of York University, gvanharten@osgoode.yorku.ca

Follow this and additional works at: http://digitalcommons.osgoode.yorku.ca/all_papers

\section{Repository Citation}

Van Harten, Gus, "Reforming the NAFTA Investment Regime" (2009). All Papers. Paper 32.

http://digitalcommons.osgoode.yorku.ca/all_papers/32 
Draft of "Reforming the NAFTA Investment Regime" in The Future of North American Trade Policy: Lessons from NAFTA, Pardee Center Task Force Report (November 2009). Includes previously unpublished appendix.

\section{REFORMING THE NAFTA INVESTMENT REGIME}

\section{Gus Van Harten ${ }^{1}$}

NAFTA's investment regime should be reformed. This paper elaborates a tiered set of reforms that are designed to (1) encourage foreign investment, while (2) affording appropriate policy space for governments to develop and regulate their economies in a sustainable manner and (3) ensuring equitable governance of investment disputes such that foreign investors are not privileged, procedurally or substantively, over domestic investors and citizens.

The proposals have been tiered according to their feasibility, based especially on whether they would require an amendment of NAFTA. An appendix outlines the reforms in more detail and indicates the extent to which each has been adopted in trade or investment agreements concluded since NAFTA.

\section{The need for reform}

\section{Investment protection and regulation for sustainable development}

An important aim of NAFTA is to encourage and protect foreign investment in order to create jobs, develop the economy, and support the shift to a green economy. Toward this end, foreign investors are given robust protections, especially by the provision in NAFTA Chapter 11 for compulsory international arbitration to decide investor claims against governments. In various respects, however, NAFTA goes too far in favoring investors over other interests.

Foreign investors are protected under NAFTA by broad standards on expropriation, non-discrimination, fair and equitable treatment, and other topics. However, the past decisions of some NAFTA tribunals have interpreted these standards in an overly expansive, pro-investor direction. This calls for clarification that the treaty does not require payment of public compensation to investors where they are affected negatively by laws or regulations passed in good faith for a public purpose (Peterson 2004, 28-32; Lawrence 2006, 294-5).

${ }^{1}$ Osgoode Hall Law School, York University, Toronto; gvanharten@osgoode.yorku.ca. 
It is likely that governments in each NAFTA state have been influenced in their regulatory decisions by the risk of a NAFTA claim. Foreign investors have shown clearly that they will challenge virtually any government measure. For example, NAFTA Chapter 11 has to date been used to challenge: measures to control gasoline content and protect groundwater resources, a legislative ban on the export of hazardous wastes, a phase-out of the agricultural chemical lindane, a court decision leading to a large punitive damages award, the creation of an ecological park, the environmental assessment of a quarry project, the regulation of open-pit mining near Native American sacred sites, and, most recently, the implementation of safety standards for foreign trucks.

Various post-NAFTA reforms appear to accept that arbitration tribunals have used their discretion to take investment treaties too far in favor of investors (see Appendix A; Thomas 2002; Gaillard 2002, 249; McLachlan 2002, 340; Tollefson 2002, 207-13 and 224-5; Munro 2005; Salgado 2006). Likewise, in its review of the Metalclad award against Mexico, the British Columbia Supreme Court observed with respect to the tribunal's definition of 'indirect expropriation' (United Mexican States 2001, para. 99):

The Tribunal gave an extremely broad definition of expropriation for the purposes of Article 1110. In addition to the more conventional notion of expropriation involving a taking of property, the Tribunal held that expropriation under the NAFTA includes covert or incidental interference with the use of property which has the effect of depriving the owner, in whole or in significant part, of the use or reasonably-to-be-expected economic benefit of property. This definition is sufficiently broad to include a legitimate rezoning of property by a municipality or other zoning authority.

Despite this, the court was unable - under the existing rules of the NAFTA regime to correct this aspect of the Metalclad award.

\section{Concerns about regulatory chill}

Pro-investor interpretations of indirect expropriation and other standards are troubling because they raise the risk of 'regulatory chill'. They enable foreign investors to entangle governments in international litigation and expose them to costly awards, even where the government has acted in good faith in pursuit of a worthy objective. In the words of one lawyer, the ability to sue under an investment treaty is:

an open invitation to unhappy investors, tempted to complain that a financial or business failure was due to improper regulation, misguided macroeconomic policy, or discriminatory treatment by the host government and delighted by the opportunity to threaten the national government with a tedious expensive arbitration (Rogers 2000). 
Various studies have raised this concern. They have highlighted the danger that NAFTA (and other investment treaties) frustrate government efforts to protect health and the environment, preserve natural resources (such as fresh water), counteract climate change, promote economic development, regulate utilities and deliver government services, make zoning decisions, reform health care, or regulate the financial sector (Werksman et al. 2001; Shrybman 2001; Flood and Epps 2002; Been and Beauvais 2003; Porterfield 2004; Lawrence 2006; Jenkins 2007; Cumming and Froehlich 2007; Gerbasi and Warner 2007; Shrybman 2008; Mann 2008).

It is difficult, if not impossible, to establish definitively that any particular measure was abandoned as a result of a NAFTA claim. But it appears that various government measures have been withdrawn in the face of threatened claims. Documented cases include, for example, withdrawn proposals in Canada to require plain packaging of cigarettes, to establish public auto insurance, and to privatize a water filtration plant (Schneiderman 2008, ch 3-4; Carrigg 2001).

\section{The Ethyl case}

Perhaps the clearest case of regulatory chill is the Ethyl arbitration. Faced with a NAFTA claim, the Canadian government withdrew its restrictions on a gasoline additive called MMT - restrictions that had been justified on the precautionary basis that burning MMT posed an unacceptable risk of nerve and brain damage in humans and especially in children - after a NAFTA tribunal allowed the manufacturer of MMT to bring its claim under Chapter 11 (Etbyl 1998). Besides withdrawing its regulation, the Canadian government also agreed to (1) issue a statement that MMT did not pose a health threat and (2) pay (U.S.) $\$ 13$ million in compensation to the manufacturer, an amount that exceeded Environment Canada's annual budget for enforcement and compliance (Traynor 1998; Schettler 1999; Fletcher 2002). The case indicates how NAFTA can be used by foreign investors to pressure a government to 'purchase its environmental sovereignty by settling its way out of Chapter XI claims' (Cumming and Froehlich 2007, 132).

Not all NAFTA claims have been successful (many are still pending). But the fact that they can be brought with such ease enables foreign investors to pressure or harass governments and to frustrate important initiatives (Cumming and Froehlich 2007, 124). An ongoing claim by Dow AgroSciences against Canada, for example - in response to Quebec's restrictions on cosmetic use of the chemical pesticide 2,4-D appears aimed as much at deterring other governments from taking similar steps to reduce pesticide use for health and environmental reasons, as much as it is meant to win compensation of $\$ 2$ million, as claimed, for the incidental impact on Dow's sales in Quebec. 


\section{The threat to financial, economic, and environmental reform}

Beyond NAFTA Chapter 11, foreign investors have used investment treaties to bring more than 250 investor-state claims against countries, usually in the developing world, over the last 15 years. They have challenged a wide range of policies and decisions. Perhaps most ominous are the 46 claims brought against Argentina for its reforms in the face of the country's financial and economic crisis in 2001. These claims have led to hundreds of millions of dollars in awards against Argentina and will likely generate billions more. Moreover, some tribunals have relied on dubious pro-investor readings of the treaties to support awards (CMS 2005). In response, Argentina has declined to pay awards, thus calling into question the utility of the system even for investors (Peterson 2009).

So long as the U.S., Canada, and Mexico do not take steps to limit their exposure to claims, they continue to put their public treasuries and regulatory processes at risk (Cumming and Froehlich 2007, 135). Law firms specializing in investment arbitration are currently drumming up business by advising investors on how to bring investorstate claims for losses caused by government reforms in response to the present financial crisis. For example, according to a client pamphlet issued recently by one London-based firm (Cameron May 2009):

States are coming under increasing pressure to take measures to bolster their national economies in response to the global economic downturn. Whist it may be appropriate for States to take measures to address the financial crisis, foreign investors could be entitled to compensation if such measures are taken in breach of the terms of investment treaties.... Since the Argentinean crisis has similarities with the financial difficulties now being encountered around the world, it is instructive to see how claims arising from huge losses suffered at the time are now being resolved....

\section{Useful development measures that are specifically probibited}

Capital controls and performance requirements are prohibited under NAFTA even though they can play an important role in avoiding financial crises or boosting productivity and employment. Tailored use of such measures should be facilitated based on evidence of their utility to prevent capital flows from undermining financial systems or to ensure that foreign investment contributes to economic development. For policy coherence, the use of these measures could be subject to supervision by a regional commission, rather than by investor-state arbitration.

\section{Equitable governance of investment disputes}

Investment disputes should be resolved fairly, via an independent adjudicative process that is accountable to public decision-makers. Investors may have good cause 
to seek protection through judicial review, even for apparently legitimate government action. But the investor-state model under NAFTA is overly dependent on a small group of arbitrators in its resolution of high matters of public policy.

For all investors, foreign or domestic, protection should be (and usually is) provided by domestic courts. Exceptionally, back-up protection may be required at the international level. But international adjudication should be an exceptional remedy, not a first resort. Foreign investors should not be able to circumvent domestic courts that offer a forum for justice that is at least as fair and independent as investor-state arbitration. In this and other respects, foreign investors should not be privileged over domestic investors and citizens, who are also profoundly affected by government decisions, and should be entitled to participate in arbitration alongside investor interests.

\section{The privileging of foreign investors over citizens}

Investor-state arbitration in its current form gives foreign investors the tremendous power to force states to submit the decisions of their legislatures, courts, and administrations to intensive review and discipline by arbitrators, outside of any court process (Gerbasi and Warner 2007, 130). Many disputes that can and should be resolved at the domestic level are thus brought before international tribunals. The system is particularly lopsided in that, while investors can claim tax-funded compensation, they are not themselves subject to regulation through the adjudicative process (Yu and Marshall 2008).

\section{The lack of independence of investor-state arbitrators}

The use of arbitration to make final decisions in public law - especially where it involves legislative choices or public budgets - undermines judicial independence. Arbitrators are reasonably seen to have an interest to interpret the law in favor of investors so as to encourage future claims and grow the arbitration industry. This apparent bias offers a credible explanation for the surprisingly pro-investor approaches of numerous tribunals (e.g. Metalclad 2000; Pope \& Talbot 2001; Tecnicas 2003; Santa Elena 2000; Maffezini 2000; CME 2001; Siemens 2004; Tokios 2004; Occidental 2004; CMS 2005). These tribunals have required payment of public compensation for a range of non-discriminatory measures where foreign investors have sustained incidental loss as a result of government action. Moreover, tribunals are insulated from review by independent judges, whether domestic or international (Sornarajah 2002; Atik 2004, 221-224; Van Harten 2007, ch 7).

These are fundamental concerns, especially because NAFTA allows for such broad review of legislative and general policy decisions. Arbitrators are given authority that goes well beyond that of courts and tribunals under other treaties (other than other trade and investment agreements). 


\section{Overarching principles and goals for reform}

\section{The principle of sustainable development}

Investment treaties should allow appropriate policy space for governments to take action, free of the risk of a ruinous damages award, to enact laws and regulations on pressing issues, so long as the measure in question does not target foreign investors in a specific way for abuse or discrimination. This policy space should be widest for legislatures and courts, and for general policy decisions of the executive. Reforms should aim to establish a regime in which states have appropriate options to regulate in good faith without risk of international claims.

\section{The principle of equitable governance}

To ensure equitable governance, NAFTA adjudication must be insulated from inappropriate influence by investors and other private actors. The process should defer to the democratic legitimacy of legislatures, the independence of domestic courts, and the expertise of executive agencies (Weiler 2000, 207-210; Brown 2002, 40-41). Foreign investors should not be allowed to circumvent domestic courts where the courts offer justice. NAFTA arbitration itself should offer an independent and fair process, both for the investor and the state, consistent with principles of judging in the constitutional traditions of the NAFTA states and in international law (UN Basic Principles 1985; Mackenzie and Sands 2003; Meron 2005; Van Harten 2008).

\section{$\underline{\text { Recommended instruments, policies and provisions }}$}

Recommended reforms to NAFTA, and their key components, are summarized below. Appendix A elaborates on these proposals in detail, including by identifying post-NAFTA agreements that already incorporate or contemplate many of the proposed reforms.

Notably, many of the revisions adopted in post-NAFTA treaties are based on the 'May 10 Agreement' in the U.S. Congress and Administration. This post-NAFTA position is an important starting point for NAFTA reform. For reasons discussed above, though, it falls short, especially because it does not address (1) the danger that arbitrators will continue to interpret the treaty - however carefully it is re-worded - in an unduly pro-investor way or (2) the procedural privileges that investor-state arbitration unfairly provides to foreign investors. 
The recommended reforms are summarized as follows.

Reform the dispute settlement regime:

- consider the option of removing the investor-state regime outright from NAFTA (requires amendment);

- provide for standing in the process for persons or entities whose interests are directly affected by an investor-state dispute, and allow states to bring counterclaims against foreign investors for breaches of their own duties or obligations (requires amendment);

- establish a regional adjudicative body to replace or supplement the role of private arbitration, and to ensure independence and enhance coherence in the decisionmaking process (requires amendment);

- provide for the members of the regional adjudicative body to develop rules to govern the resolution of investor-state disputes (requires amendment);

- as a temporary measure to ensure independence, and as provided for in NAFTA Article 1124(4) itself, designate a roster of experts - preferably sitting judges from which presiding arbitrators must be chosen (does not require amendment of the NAFTA text);

Ensure that investor-state arbitration is an exceptional remedy:

- take steps to limit forum-shopping and 'claims of convenience' by non-NAFTA investors (may not require amendment);

- preclude foreign investors from circumventing domestic courts where the courts offer justice (may not require amendment);

- expand NAFTA's screening mechanism to ensure flexibility and predictability in key fields of regulation, such as financial regulation and health/ environmental protection (requires amendment);

Clarify broadly-framed substantive standards:

- limit the concepts of indirect expropriation and 'fair and equitable treatment' to preclude their application to non-discriminatory measures that are adopted in good faith for a public purpose, based for example on the awards in Methanex (2005) and Glamis Gold (2009) (does not require amendment);

- clarify that national treatment requires evidence of either (1) intentional discrimination or (2) de facto discrimination against foreign investors as a group, based for example on the $A D F$ award (2003) (does not require amendment);

- clarify that most-favored-nation treatment does not defeat exceptions in NAFTA or extend to dispute settlement provisions of other treaties, based for example on the Plama award (2005) (does not require amendment); 


\section{Check the discretion of investor-state tribunals:}

- direct tribunals to defer to legislative and judicial decisions, and to policy decisions of the executive, where the decision does not target foreign investors for abusive or discriminatory treatment (does not require amendment);

- clarify that tribunals should defer to the shared views of the NAFTA governments participating in an investor-state arbitration regarding the proper interpretation of NAFTA (does not require amendment);

- clarify that tribunals may award partial damages, or simply a costs award or declaratory award, as adequate satisfaction for a foreign investor, and that any damages award should account for the degree of blameworthiness of the respondent state (does not require amendment);

\section{Provide exceptions to protect legitimate regulation:}

- incorporate exceptions from post-NAFTA treaties that aim to safeguard the financial system (may not require amendment);

- allow for tailored use of capital controls and performance requirements where justified to maintain financial stability or boost productivity and employment (requires amendment);

- extend NAFTA's general exceptions to its investment chapter (requires amendment);

\section{Revise the treaty's statement of objectives:}

- revise the statement of objectives of both NAFTA and its investor-state regime by referring, among other things, to the equitable governance of investment disputes based on judicial openness, independence, and accountability (requires amendment).

Not all of these reforms require amendment of NAFTA. NAFTA authorizes the Free Trade Commission - made up of Cabinet-level representatives of each NAFTA state - to make interpretations of the treaty that are binding on tribunals. This is an important tool to clarify the treaty. That said, other reforms that require amendment should also be pursued in order to address key concerns. 


\section{REFERENCES}

ADF Group Inc v United States of America (Merits) (9 January 2003), 18 ICSID Review 195, 6 ICSID Reports 470, 15(3) World Trade and Arbitration Materials 55.

Afilalo, A. (2001) 'Constitutionalizing Through the Back Door: A European Perspective on NAFTA's Investment Chapter' 34 NYU Journal of International Law \& Policy 1.

Atik, J. (2004) 'Repenser NAFTA Chapter 11: A Catalogue or Legitimacy Critiques' 3 Asper Review of International Business and Trade Law 215.

Been, V.L. and J.C. Beauvais (2008) 'The Global Fifth Amendment: NAFTA's Investment Protections and the Misguided Quest for an International 'Regulatory 'Takings' Doctrine' 78 New York University Law Review 30.

Bipartisan Trade Promotion Authority Act of 2002, Div B, Title XXI, Trade Act of 2002, Pub L No 107-210, 116 USC 933, s 2102(3) (2002) (USA).

Brasserie du Pêcheur SAv Germany; Secretary of State for Transport, ex parte Factortame Ltd and Others (No 46 \& 48/93), (1996) 1 Common Market Law Review 889.

Brown, D. (2002) 'Commentary' in L. Ritchie Dawson, ed., Whose Rights? The NAFTA Chapter 11 Debate, Ottawa: Centre for Trade Policy and Law.

Carrigg, D. (2001) 'GVRD pulls plug on plan to privatize water filtration plant' Vancouver Courier - On Line (5 July 2001).

CME Republic BV v Czech Republic (Merits) (13 September 2001), 14(3) World Trade and Arbitration Materials 109.

CMS Cameron May, 'International arbitration: State liability to private investors in an economic crisis' Law-Now (30 March 2009).

CMS Gas Transmission Company v Argentine Republic (Merits) (12 May 2005), 44

International Legal Materials 1205, 17(5) World Trade and Arbitration Materials 63.

Coe Jr., J.J. (2005) 'The State of Investor-State Arbitration - Some Reflections on Professor Brower's Plea for Sensible Principles' 20 American University International Law Review 929.

Compañia del Desarrollo de Santa Elena, $S A v$ Republic of Costa Rica (Merits) (17 February 2000), 15 ICSID Review 169, 39 International Legal Materials 317, 5 ICSID Reports 157, 13(1) World Trade and Arbitration Materials 81. 
Costa, J.-P. (2001) 'The Provision of Compensation Under Article 41 of the European Convention on Human Rights', Address to the British Institute of International and Comparative Law (7 December 2001).

Cumming, J. and R. Froehlich (2007), 'NAFTA Chapter XI and Canada's Environmental Sovereignty: Investment Flows, Article 1110 and Alberta's Water Act' 65 University of Toronto Faculty of Law Review 107.

Dezaley, Y (1996) 'Between the State, Law, and the Market: The Social and Professional Stakes in the Construction and Definition of a Regulatory Arena' in W.W. Bratton et al., eds., International Regulatory Competition and Coordination, Oxford: Clarendon Press.

Ethyl Corporation v Government of Canada (Jurisdiction) (24 June 1998), 38 International Legal Materials 708.

Fletcher, G. (2002), 'U.S. bans it; Canada burns it' National Post (6 September 2002).

Flood, C.M. and T.D. Epps (2002), 'Have We Traded Away the Opportunity for Innovative Health Care Reform? The Implications of the Nafta for Medicare' 47 McGill Law Review 747.

Francovich and Bonifaci v Republic of Italy (No 6 and 9/90), [1991] ECR I-5357, (1993) 2 CML Rev 66.

Free Trade Commission (NAFTA) (2001), 'Notes of Interpretation of Certain Chapter 11 Provisions' (31 July 2001).

Free Trade Commission (NAFTA) (2003), 'Statement of the Free Trade Commission on non-disputing party participation' (17 October 2003).

Gagné, G. and J.-F. Morin (2006) 'The Evolving American Policy on Investment Protection: Evidence from Recent FTAs and the 2004 Model BIT' 9 Journal of International Economic Law 357.

Gaillard, E. (2002) 'Commentary’ 18 Arbitration International 247.

GAMI Investments, Inc v Government of the United Mexican States (Merits) (15 November 2004), 44 International Legal Materials 545, 17(2) World Trade and Arbitration Materials 127. 
Gantz, D.A. (2005) 'An Appellate Mechanism for Review of Arbitral Decisions in Investor-State Disputes: Prospects and Challenges’, Berkeley Electronic Press Working Paper No. 703.

Gantz, D.A. (2006), 'The United States and NAFTA Dispute Settlement: Ambivalence, Frustration and Occasional Defiance', Arizona Legal Studies Discussion Paper No. 06-26.

Gerbasi, J. and M.E. Warner (2007), 'Privatization, Public Goods, and the Ironic Challenge of Free Trade Agreements’ 39 Administration \& Society 127.

Glamis Gold v USA (Merits) (6 August 2009) (available online: U.S. State Department http://www.state.gov/documents/organization/125798.pdf).

Goldhaber, M.D. (2004) 'Wanted: A World Investment Court' The American Lanyer (Summer 2004).

International Institute for Sustainable Development (IISD) (2001) 'Note on NAFTA Commission's July 31, 2001, Initiative to Clarify Chapter 11 Investment Provisions’.

IISD (2005) 'IISD Model International Agreement on Investment for Sustainable Development' (April 2005).

Jenkins, B.W. (2007) 'The Next Generation of Chilling Uncertainty: Indirect Expropriation Under CAFTA and its Potential Impact on Environmental Protection' 12 Ocean and Coastal Law Journal 269.

Johnson, J.R. (2002) 'How Will International Trade Agreements Affect Canadian Health Care?', Discussion Paper No 22 for the Commission on the Future of Health Care in Canada (September 2002).

Jones, R.C. (2002) 'NAFTA Chapter 11 Investor-to-State Dispute Resolution: A Shield to be Embraced or a Sword to be Feared?' [2002] Brigham Young University Law Review 527.

Lawrence, J.C. (2006) 'Chicken Little Revisited: NAFTA Regulatory Expropriations After Methanex' 41 Georgia Law Review 261.

Lazar, L. (2000), 'Dispute resolution: Secret corporate weapon?' 1(3) Journal of Global Financial Markets (Winter 2000).

Loewen Group, Inc and Raymond L Loewen v United States of America (Merits) (26 June 2003), 42 International Legal Materials 811, 7 ICSID Reports 442, 15(5) World Trade and Arbitration Materials 97. 
Mackenzie, R. and P. Sands (2003) 'International Courts and Tribunals and the Independence of the International Judge' 44 Harvard International Law Journal 271.

Maffezini (Emilio Agustin) v Kingdom of Spain (Jurisdiction) (25 January 2000), 16 ICSID Review 212, 124 ILR 9.

Mann, H. (2008) 'International Investment Agreements, Business and Human Rights: Key Issues and Opportunities', Report for the International Institute for Sustainable Development (February 2008).

McLachlan, C. (2002) 'Commentary: The Broader Context' 18 Arbitration International 339.

Meron, T. (2005) 'Judicial Independence and Impartiality in International Criminal Tribunals' 99 American Journal of International Law 359.

Metalclad Corporation v United Mexican States (Merits) (30 August 2000), 16 ICSID Review 168, 40 International Legal Materials 36, 5 ICSID Reports 212, 13(1) World Trade and Arbitration Materials 45.

Methanex Corporation v United States of America (Merits) (3 August 2005), 44 International Legal Materials 1345, 17(6) World Trade and Arbitration Materials 61.

Munro, M.A. (2005) 'Expropriating Expropriation Law: The Implications of the Metalclad Decision on Canadian Expropriation Law and Environmental Land-Use Regulation' 5 Asper Review of International Business \& Trade Law 75.

Occidental Exploration and Production Company v Republic of Ecuador (Merits) (1 July 2004), 17(1) World Trade and Arbitration Materials 165.

Peterson, L.E. (2004) 'Bilateral Investment Treaties and Development PolicyMaking', Report for the International Institute for Sustainable Development (November 2004).

Peterson, L.E. (2009) 'Argentine Crisis Arbitration Awards Pile Up, but Investors Still Wait for a Payout' American Lawyer (25 June 2009).

Plama Consurtium Limited $v$ Republic of Bulgaria (Jurisdiction) (8 February 2005), 20 ICSID Review 262, 44 International Legal Materials 721.

Poirier, M. (2003) 'The NAFTA Chapter 11 Expropriation Debate Through the Eyes of a Property Theorist' 33 Environmental Law 851. 
Pope \& Talbot Inc v Government of Canada (Merits, Phase 2) (10 April 2001), 13(4) World Trade and Arbitration Materials 61.

Porterfield, M.C. (2004) 'International Expropriation Rules and Federalism' 4 Stanford Environmental Law Journal 3.

Rogers, W. (2000) 'Emergence of the International Centre for Settlement of Investment Disputes (ICSID) as the Most Significant Forum for Submission of Bilateral Investment Treaty Disputes', Presentation to the Inter-American Development Bank Conference (26-7 October 2000).

Salgado, V. (2006) 'The Case Against Adopting BIT Law in the FTAA Framework' 2006 Wisconsin Law Review 1024.

Sauvant K.P. et al. (2009), 'Memo - Improving the International Investment Regime: priorities for the new U.S. Administration', Columbia University (29 January 2009).

Schettler, T. (1999), 'Manganese in Gasoline: A Case Study of the Need for Precautionary Action' in Raffensperger and Tickner, eds., Protecting Public Health and the Environment, Washington, D.C.: Island Press.

Schneiderman, D. (2008) Constitutionalizing Economic Globalization, Cambridge: Cambridge University Press.

SD Myers, Inc v Government of Canada (Merits) (12 November 2000), 40 International Legal Materials 1408, 15(1) World Trade and Arbitration Materials 184.

Shrybman, S. (2001) 'A Legal Opinion Concerning the Potential Impacts of International Trade Disciplines on Proposals to Establish a Public-Private Partnership to Design, Build and Operate a Water Filtration Plant in the Seymour Reservoir', Prepared for the Canadian Union of Public Employees (17 July 2001).

Shrybman, S. (2008), 'Pemex, Privatization and the NAFTA Trap', Presentation on behalf of the Canadian Union of Public Employees and the Communications, Energy, and Paperworkers Union of Canada (June 2008).

Siemens AG v Argentine Republic (Jurisdiction) (3 August 2004), 44 International Legal Materials 138.

Sornarajah, M. (1997) ‘Power and Justice in Foreign Investment Arbitration’ 14(3) Journal of International Arbitration 103. 
Sornarajah, M. (2002) 'The Clash of Globalisations and the International Law on Foreign Investment', Presentation to the Centre for Trade Policy and Law, Ottawa (12 September 2002).

Tams, C.J. (2007) 'Is There a Need for an ICSID Appellate Structure' in Hofmann and Tams, eds., The International Convention for the Settlement of Investment Disputes: Taking Stock. After 40 Years, Baden-Baden: Nomos.

Tecnicas Medioambientales Tecmed, SA v United Mexican States (Merits) (29 May 2003), 19 ICSID Review 158, 43 International Legal Materials 133.

Thomas, J.C. (2002) 'Reflections on Article 1105 of NAFTA: History, State Practice and the Influence of Commentators' 17 ICSID Review 21.

Tokios Tokelès v Ukraine (Jurisdiction) (29 April 2004), 20 ICSID Review 205, 16(4) World Trade and Arbitration Materials 75.

Tollefson, C. (2002) 'Metalclad v. United Mexican States Revisited: Judicial Oversight of NAFTA's Chapter Eleven Investor-State Claim Process' 11 Minnesota Journal of Global Trade 183.

Traynor, K. (1998), 'How Canada Became a Shill for Ethyl Corp.' 23(3) Intervenor.

United Mexican States v Metalclad Corporation (2001) 89 BCLR (3rd) 359, 38 CELR 284, 13(5) World Trade and Arbitration Materials 219 (British Columbia Supreme Court).

United Nations (UN) (1985), 'Basic Principles on the Independence of the Judiciary', adopted by the Seventh United Nations Congress on the Prevention of Crime and the Treatment of Offenders, Milan, 26 August-6 September 1985; endorsed by GA Res 40/32 and 40/146, UN GAOR, 40th Sess, UN Doc A/RES/40/32 and A/RES/40/146 (1985).

Van Harten, G. (2007) Investment Treaty Arbitration and Public Law, Oxford: Oxford University Press.

Van Harten, G. (2008), 'A Case for an International Investment Court', SSRN Paper No. 1153432, Working Paper No. 22/08 for the Society of International Economic Law Inaugural Conference, Geneva (15-17 July 2008).

Weiler, J.H.H. (2000) 'Epilogue: Towards a Common Law of International Trade' in J.H.H. Weiler, ed., The EU, the WTO, and the NAFTA, Oxford: Oxford University Press. 
Werksman, J., K.A. Baumert, and N.K. Dubash (2001) 'Will International Investment Rules Obstruct Climate Protection Policies?', Report for the World Resources Institute (April 2001).

Werner, J. (1997) 'The Trade Explosion and Some Likely Effects on International Arbitration' 14(2) Journal of International Arbitration 5.

Yu, and F. Marshall (2008), 'Investor's Obligations and Host State Policy Space', Background paper for the $2^{\text {nd }}$ Annual Forum of Developing Country Investment Negotiators (3-4 November 2008). 


\section{APPENDIX A \\ NAFTA'S INVESTMENT REGIME - PROPOSED REFORMS}

\begin{tabular}{|c|c|c|c|c|}
\hline Proposed reform & $\begin{array}{l}\text { Relevant } \\
\text { principle (s) }\end{array}$ & Comment/rationale & $\begin{array}{l}\text { Requires } \\
\text { amendment? }\end{array}$ & References \\
\hline \multicolumn{5}{|c|}{ REFORM THE DISPUTE SETTLEMENT REGIME } \\
\hline $\begin{array}{l}\text { Consider removing the investor- } \\
\text { state mechanism from NAFTA } \\
\text { and replacing it with an inter- } \\
\text { governmental or inter-state } \\
\text { dispute settlement process. }\end{array}$ & $\begin{array}{l}\text { Equitable } \\
\text { governance - } \\
\text { privileging of } \\
\text { foreign investors }\end{array}$ & $\begin{array}{l}\text { Ensure like treatment of } \\
\text { investors and non-investors. } \\
\text { Many trade agreements do not } \\
\text { provide for investor-state } \\
\text { arbitration, indicating that other } \\
\text { methods of dispute resolution } \\
\text { would satisfy U.S. (and likely } \\
\text { other NAFTA states') } \\
\text { negotiating objectives. }\end{array}$ & Yes & $\begin{array}{l}\text { e.g. U.S.-Australia Free Trade } \\
\text { Agreement; U.S.-Israel Free Trade } \\
\text { Agreement. }\end{array}$ \\
\hline $\begin{array}{l}\text { Provide for sub-national } \\
\text { government or private parties to } \\
\text { be given standing in investor-state } \\
\text { adjudication where their interests } \\
\text { are directly affected by the } \\
\text { dispute. }\end{array}$ & $\begin{array}{l}\text { Equitable } \\
\text { governance - } \\
\text { privileging of } \\
\text { foreign investors }\end{array}$ & $\begin{array}{l}\text { Limits the one-sidedness of the } \\
\text { process by ensuring a wider } \\
\text { range of direct interests have full } \\
\text { access to the decision-making } \\
\text { process. }\end{array}$ & Yes & $\begin{array}{l}\text { CAFTA, Article 10.20(3); U.S.-Chile } \\
\text { FTA, Article 10.19(3); U.S.-Rwanda } \\
\text { BIT, Article 28(3); Canada Model BIT, } \\
\text { Article } 39 \text { (each providing for amicus } \\
\text { curiae representation, but not direct } \\
\text { standing, for non-investors). }\end{array}$ \\
\hline $\begin{array}{l}\text { Establish a regional adjudicative } \\
\text { body to decide NAFTA Chapter } \\
11 \text { disputes, consisting of } \\
\text { adjudicators who enjoy objective } \\
\text { guarantees of their independence } \\
\text { and impartiality. }\end{array}$ & $\begin{array}{l}\text { Equitable } \\
\text { governance - } \\
\text { adjudicative } \\
\text { independence and } \\
\text { impartiality }\end{array}$ & $\begin{array}{l}\text { The body could either replace } \\
\text { the existing arbitration process } \\
\text { or provide for an appellate } \\
\text { process. The former is preferred } \\
\text { to avoid duplication and ensure } \\
\text { independence by removing the } \\
\text { role of the arbitration industry. } \\
\text { The body should be designed to } \\
\text { allow it to be extended to other } \\
\text { trade or investment agreements, } \\
\text { with the consent of the relevant } \\
\text { states. }\end{array}$ & Yes & $\begin{array}{l}\text { CAFTA, Article 10.20(10); U.S.-Chile } \\
\text { FTA, Article 10.19(10); U.S.-Colombia } \\
\text { FTA, Article 10.20(10); U.S.-Peru FTA, } \\
\text { Article 10.20(10); U.S. Model BIT, } \\
\text { Article 28(10) (each referring to the } \\
\text { prospect of an appellate body). } \\
\text { IISD Model International Investment } \\
\text { Agreement (2005), Article } 40 .\end{array}$ \\
\hline
\end{tabular}




\begin{tabular}{|c|c|c|c|c|}
\hline $\begin{array}{l}\text { Provide for members of a regional } \\
\text { adjudicative body to develop rules } \\
\text { to govern investor-state disputes } \\
\text { according to principles of judicial } \\
\text { openness, independence, and } \\
\text { accountability. } \\
\text { Alternatively, provide for the Free } \\
\text { Trade Commission to make such } \\
\text { rules. }\end{array}$ & $\begin{array}{l}\text { Equitable } \\
\text { governance - } \\
\text { openness and } \\
\text { fairness of the } \\
\text { decision-making } \\
\text { process }\end{array}$ & $\begin{array}{l}\text { The rules of arbitration used } \\
\text { under NAFTA are based on the } \\
\text { model of commercial arbitration } \\
\text { and are not suited to resolution } \\
\text { of high public policy. } \\
\text { The rules of international courts } \\
\text { and tribunals typically reflect the } \\
\text { principles of judicial openness, } \\
\text { independence, and accountability } \\
\text { to a greater degree than rules } \\
\text { used in investor-state arbitration, } \\
\text { including the ICSID Rules, } \\
\text { ICSID Additional Facility Rules, } \\
\text { UNCITRAL Rules, ICC Rules, } \\
\text { LCIA Rules, and SCC Rules. }\end{array}$ & Yes & $\begin{array}{l}\text { CAFTA, Article 10.21; U.S. Chile FTA, } \\
\text { Article 10.20; U.S.-Colombia FTA, } \\
\text { Article 10.21; U.S.-Peru FTA, Article } \\
\text { 10.21; U.S.-Uruguay BIT, Article 20; } \\
\text { U.S.-Rwanda BIT, Article 29; U.S. } \\
\text { Model BIT, Article 29; Canada-Peru } \\
\text { FTA, Article 835; Canada-Colombia } \\
\text { FTA, Article 830; Canada Model BIT, } \\
\text { Article 38; Norway draft Model BIT, } \\
\text { Article } 19 \text { (each providing a firmer } \\
\text { commitment to openness than does the } \\
\text { NAFTA Free Trade Commission's } \\
\text { interpretive note of } 31 \text { July 2001). } \\
\text { Canada Model BIT, Article 27(2) } \\
\text { (allowing a commission equivalent to } \\
\text { the NAFTA Free Trade Commission } \\
\text { to make arbitration rules that bind } \\
\text { tribunals under the treaty). }\end{array}$ \\
\hline $\begin{array}{l}\text { As a temporary measure pending } \\
\text { further reform, and as already } \\
\text { provided for in NAFTA, establish } \\
\text { a roster of arbitrators from which } \\
\text { presiding arbitrators must be } \\
\text { appointed. }\end{array}$ & $\begin{array}{l}\text { Equitable } \\
\text { governance - } \\
\text { adjudicative } \\
\text { independence and } \\
\text { impartiality }\end{array}$ & $\begin{array}{l}\text { Implementing this NAFTA } \\
\text { commitment would assist to } \\
\text { enhance confidence in Chapter } \\
11 \text { arbitration, especially in the } \\
\text { appointment of presiding } \\
\text { arbitrators. } \\
\text { Presiding arbitrators should be } \\
\text { appointed on a rotating (or } \\
\text { otherwise objective) basis, and } \\
\text { the number on the roster would } \\
\text { ideally be less than the } 45 \text { called } \\
\text { for in NAFTA Article } 1124 \text {. To } \\
\text { ensure independence, members } \\
\text { of the roster could be sitting }\end{array}$ & No & $\begin{array}{l}\text { NAFTA Article 1124(3) and (4) and } \\
\text { Article 1126(5). } \\
\text { IISD Model International Investment } \\
\text { Agreement (2005), Article 40(E). }\end{array}$ \\
\hline
\end{tabular}




\begin{tabular}{|l|l|l|l|l|}
\hline & & $\begin{array}{l}\text { judges with experience in } \\
\text { international law, reflecting } \\
\text { domestic courts' objective } \\
\text { guarantees of independence. }\end{array}$ & & \\
\hline $\begin{array}{l}\text { Direct that the disputing parties, } \\
\text { and the appointing authority, must } \\
\text { ensure that any arbitrators they } \\
\text { appoint have expertise in the } \\
\text { relevant field of regulation, as } \\
\text { identified by the respondent state. }\end{array}$ & $\begin{array}{l}\text { Sustainable } \\
\text { development - } \\
\text { appropriate policy } \\
\text { space }\end{array}$ & $\begin{array}{l}\text { Ensures that arbitrators have } \\
\text { expertise in the relevant field of } \\
\text { government regulation rather } \\
\text { than simply international law or } \\
\text { investment. }\end{array}$ & Yes & $\begin{array}{l}\text { U.S. Model BIT, Article 20(2)(c)(i) and } \\
\text { (providing for such expertise where } \\
\text { the claim relates to financial services). }\end{array}$ \\
\hline $\begin{array}{l}\text { Develop a code of conduct for } \\
\text { investor-state adjudicators that } \\
\text { accounts for the uniquely public } \\
\text { character of investor-state } \\
\text { disputes. }\end{array}$ & $\begin{array}{l}\text { Equitable } \\
\text { governance }- \\
\text { adjudicative } \\
\text { independence and } \\
\text { impartiality }\end{array}$ & $\begin{array}{l}\text { Ameliorates, to an extent, } \\
\text { concerns about the lack of } \\
\text { independence and impartiality in } \\
\text { investor-state arbitration. }\end{array}$ & No & NAf4). \\
\hline
\end{tabular}




\begin{tabular}{|c|c|c|c|c|}
\hline Proposed reform & $\begin{array}{l}\text { Relevant } \\
\text { principle(s) }\end{array}$ & Comment/rationale & $\begin{array}{l}\text { Requires } \\
\text { amendment? }\end{array}$ & References \\
\hline \multicolumn{5}{|c|}{ INVESTOR-STATE ARBITRATION AS AN EXCEPTIONAL REMEDY } \\
\hline $\begin{array}{l}\text { Provide expressly that a NAFTA } \\
\text { Party may deny the benefit of the } \\
\text { investment chapter to a foreign } \\
\text { company that has no substantial } \\
\text { business activities (or, as a more } \\
\text { stringent control, its corporate } \\
\text { head office) in the territory of a } \\
\text { NAFTA state. }\end{array}$ & $\begin{array}{l}\text { Sustainable } \\
\text { development - } \\
\text { appropriate policy } \\
\text { space } \\
\text { Equitable } \\
\text { governance - } \\
\text { privileging of } \\
\text { foreign investors }\end{array}$ & $\begin{array}{l}\text { Allows a respondent state to } \\
\text { prevent forum-shopping and } \\
\text { 'claims of convenience' by } \\
\text { foreign investors from outside } \\
\text { the NAFTA region, consistent } \\
\text { with post-NAFTA treaties. }\end{array}$ & Yes & $\begin{array}{l}\text { U.S.-Colombia FTA, Article 10.12(2); } \\
\text { U.S.-Rwanda BIT, Article 17(2). } \\
\text { U.S. Model BIT, Article 17(2). } \\
\text { Canada-Colombia FTA, Article 814(2). } \\
\text { Norway draft Model BIT, Article } \\
\text { 2(1)(ii). }\end{array}$ \\
\hline $\begin{array}{l}\text { Expand NAFTA's screening } \\
\text { mechanisms to include other } \\
\text { fields where regulatory flexibility } \\
\text { is important. }\end{array}$ & $\begin{array}{l}\text { Sustainable } \\
\text { development - } \\
\text { appropriate policy } \\
\text { space }\end{array}$ & $\begin{array}{l}\text { Permits the affected NAFTA } \\
\text { states to pre-empt frivolous or } \\
\text { unduly expansionist claims by } \\
\text { foreign investors in sensitive } \\
\text { fields, such as financial } \\
\text { regulation and health/ } \\
\text { environmental protection. } \\
\text { Allow agencies of the } \\
\text { respondent state and the } \\
\text { investor's home state, or the } \\
\text { Free Trade Commission, an } \\
\text { opportunity to re-affirm their } \\
\text { right to regulate by agreeing that } \\
\text { a challenged measure does not } \\
\text { violate NAFTA and disposing of } \\
\text { the claim. }\end{array}$ & Yes & $\begin{array}{l}\text { Screening mechanisms under NAFTA } \\
\text { currently apply only to expropriation } \\
\text { claims involving taxation (Article } \\
2103(6) \text { ), measures subject to the } \\
\text { financial services exception (Article } \\
\text { 1410), and the interpretation of } \\
\text { annexes (Article 1132). } \\
\text { Canada Model BIT, Article } 17 .\end{array}$ \\
\hline $\begin{array}{l}\text { Re-institute the duty of foreign } \\
\text { investors to exhaust domestic } \\
\text { remedies that are reasonably } \\
\text { available to them. Alternatively, } \\
\text { allow respondent states to defend }\end{array}$ & $\begin{array}{l}\text { Equitable } \\
\text { governance - } \\
\text { privileging of } \\
\text { foreign investors }\end{array}$ & $\begin{array}{l}\text { Ensures that investor-state } \\
\text { arbitration is a remedy of last } \\
\text { resort relative to domestic courts } \\
\text { that offer justice. }\end{array}$ & Yes & Norway draft Model BIT, Article 15(3). \\
\hline
\end{tabular}




\begin{tabular}{|c|c|c|c|c|}
\hline $\begin{array}{l}\text { against a claim by showing that } \\
\text { domestic remedies are reasonably } \\
\text { available. }\end{array}$ & & & & \\
\hline $\begin{array}{l}\text { Clarify that a foreign investor, to } \\
\text { establish a breach of a NAFTA } \\
\text { standard, must first challenge the } \\
\text { measure in a reasonably-available } \\
\text { domestic forum. Alternatively, } \\
\text { clarify that failure by a foreign } \\
\text { investor to exhaust domestic } \\
\text { remedies supports an interpretive } \\
\text { presumption by the tribunal for } \\
\text { issues on which the investor had } \\
\text { reasonable opportunity to obtain } \\
\text { justice at the domestic level. }\end{array}$ & $\begin{array}{l}\text { Equitable } \\
\text { governance - } \\
\text { privileging of } \\
\text { foreign investors }\end{array}$ & $\begin{array}{l}\text { Ensures that the challenged } \\
\text { decision is in fact a final decision } \\
\text { of the respondent state's } \\
\text { decision-makers. }\end{array}$ & No & $\begin{array}{l}\text { This approach is consistent with the } \\
\text { reasoning of the Loewen award, which } \\
\text { was interpreting NAFTA Article } 1105 \\
\text { in relation to a domestic court decision } \\
\text { (Loewen } 2003 \text {, para. } 143 \text { and 156). }\end{array}$ \\
\hline $\begin{array}{l}\text { Clarify that foreign investors who } \\
\text { are only minority shareholders in a } \\
\text { domestic company in the } \\
\text { respondent state may bring a } \\
\text { NAFTA claim with respect to } \\
\text { their shareholder interest, but not } \\
\text { with respect to the interests of the } \\
\text { domestic company as a whole. }\end{array}$ & $\begin{array}{l}\text { Equitable } \\
\text { governance - } \\
\text { privileging of } \\
\text { foreign investors } \\
\text { Sustainable } \\
\text { development - } \\
\text { appropriate policy } \\
\text { space }\end{array}$ & $\begin{array}{l}\text { Ensures that foreign investors } \\
\text { cannot manipulate investor-state } \\
\text { arbitration so as to duplicate or } \\
\text { circumvent domestic courts. } \\
\text { In the GAMI case, both Mexico } \\
\text { (as the respondent state) and the } \\
\text { U.S. (the investor's home state) } \\
\text { called for the tribunal to adopt } \\
\text { this interpretation of NAFTA. } \\
\text { However, the tribunal rejected } \\
\text { their submissions in favor of an } \\
\text { expansive reading that apparently } \\
\text { allows minority shareholders to } \\
\text { advance claims beyond their } \\
\text { shareholder interest ( } G A M I \\
\text { 2004, para. 29-33). }\end{array}$ & No & U.S.-Chile FTA, Annex 10-C(1)(b). \\
\hline $\begin{array}{l}\text { Clarify that a domestic company } \\
\text { that lacks the characteristics of an }\end{array}$ & $\begin{array}{l}\text { Equitable } \\
\text { governance - }\end{array}$ & $\begin{array}{l}\text { May limit unduly expansive } \\
\text { interpretations by tribunals, by }\end{array}$ & No & U.S.-Rwanda BIT, Article 1, note 1. \\
\hline
\end{tabular}




\begin{tabular}{|l|l|l|l|l|}
\hline investment is not an investment. & $\begin{array}{l}\text { privileging of } \\
\text { foreign investors. }\end{array}$ & $\begin{array}{l}\text { ensuring that genuine 'foreign } \\
\text { investors' only may bring } \\
\text { investor-state claims. }\end{array}$ & Norway draft Model BIT, Article 2(2). \\
\hline $\begin{array}{l}\text { Limit access to investor-state } \\
\text { arbitration in relation to debt } \\
\text { restructuring. }\end{array}$ & $\begin{array}{l}\text { Sustainable } \\
\text { development - } \\
\text { stability of the } \\
\text { financial system }\end{array}$ & $\begin{array}{l}\text { Allows for an orderly process of } \\
\text { negotiation and restructuring by } \\
\text { creditors as a group, from of } \\
\text { investor claims. }\end{array}$ & Yes & $\begin{array}{l}\text { U.S.-Colombia FTA, Annex 10-F. } \\
\text { U.S.-Peru FTA, Annex 10-F. } \\
\text { U.S.-Uruguay BIT, Annex G. }\end{array}$ \\
\hline $\begin{array}{l}\text { Exclude portfolio investment } \\
\text { from the definition of investment } \\
\text { or limit access to investor-state } \\
\begin{array}{l}\text { arbitration where the claim arises } \\
\text { from portfolio investment. }\end{array}\end{array}$ & $\begin{array}{l}\text { Sustainable } \\
\text { development - } \\
\text { stability of the } \\
\text { financial system }\end{array}$ & $\begin{array}{l}\text { Preserves regulatory flexibility } \\
\text { that may undermine financial } \\
\text { stability. }\end{array}$ & Yes & $\begin{array}{l}\text { IISD Model International Investment } \\
\text { Agreement (2005), Article 2(C)(v)(a). }\end{array}$ \\
\hline
\end{tabular}




\begin{tabular}{|c|c|c|c|c|}
\hline Proposed reform & \begin{tabular}{|l|} 
Relevant \\
principle $(s)$
\end{tabular} & Comment/rationale & $\begin{array}{l}\text { Requires } \\
\text { amendment? }\end{array}$ & References \\
\hline \multicolumn{5}{|c|}{ CLARIFYTHE SUBSTANTIVE STANDARDS } \\
\hline $\begin{array}{l}\text { Clarify the meaning of indirect } \\
\text { expropriation. }\end{array}$ & $\begin{array}{l}\text { Sustainable } \\
\text { development - } \\
\text { appropriate policy } \\
\text { space }\end{array}$ & $\begin{array}{l}\text { Responds to past tribunals' } \\
\text { unduly expansive, pro-investor } \\
\text { interpretations of indirect } \\
\text { expropriation, consistent with } \\
\text { post-NAFTA treaties. }\end{array}$ & No & $\begin{array}{l}\text { CAFTA Annex 10-C. } \\
\text { U.S.-Chile FTA, Annex 10-D. } \\
\text { U.S.-Colombia FTA, Annex 10-B. } \\
\text { U.S.-Peru FTA, Annex 10-B. } \\
\text { U.S.-Uruguay BIT, Annex B and } \\
\text { Protocol (section 3). } \\
\text { U.S.-Rwanda BIT, Annex B. } \\
\text { U.S. Model BIT, Annex B. } \\
\text { Canada-Peru FTA, Annex 812.1. } \\
\text { Canada-Colombia FTA, Annex 811. } \\
\text { Canada Model BIT, Annex B.13(1). } \\
\text { Norway draft Model BIT, Article 6(2). } \\
\text { IISD Model International Investment } \\
\text { Agreement (2005), Article 8(I). } \\
\text { See especially the Methanex } \\
\text { interpretation of Article } 1110 \text {, where } \\
\text { the tribunal concluded that non- } \\
\text { discriminatory measures adopted for a } \\
\text { public purpose, in the absence of any } \\
\text { breach of a specific commitment to the } \\
\text { investor, are not deemed expropriatory } \\
\text { (Methanex } 2005 \text {, Part IV - Chapter D - } \\
\text { para. } 7) \text {. }\end{array}$ \\
\hline $\begin{array}{l}\text { Clarify (and limit) the terms of } \\
\text { 'fair and equitable treatment' and } \\
\text { 'full protection and security' as } \\
\text { elements of the minimum }\end{array}$ & $\begin{array}{l}\text { Sustainable } \\
\text { development - } \\
\text { appropriate policy } \\
\text { space }\end{array}$ & $\begin{array}{l}\text { Supplements the existing } \\
\text { interpretive note on NAFTA } \\
\text { Article } 1105 \text {, consistent with } \\
\text { post-NAFTA treaties that were }\end{array}$ & No & $\begin{array}{l}\text { CAFTA, Article } 10.5(2) \text { and (3). } \\
\text { U.S.-Chile FTA, Article 10.4(2) and (3). } \\
\text { U.S.-Colombia FTA, Article 10.5(2) } \\
\text { and (3). }\end{array}$ \\
\hline
\end{tabular}




\begin{tabular}{|c|c|c|c|c|}
\hline $\begin{array}{l}\text { standard in customary } \\
\text { international law. }\end{array}$ & & $\begin{array}{l}\text { themselves revised to address } \\
\text { pro-investor interpretations by } \\
\text { NAFTA and other tribunals. } \\
\text { 'Fair and equitable treatment' has } \\
\text { been invoked most frequently by } \\
\text { tribunals to find violations of } \\
\text { investment treaties and to issue } \\
\text { awards against states, including } \\
\text { via expansive readings of this } \\
\text { term (e.g. CMS 2005). Indeed, a } \\
\text { NAFTA arbitrator in one case } \\
\text { expressed his preference to find } \\
\text { a violation of fair and equitable } \\
\text { treatment in order to displace } \\
\text { public concerns about the } \\
\text { expropriation standards (SD } \\
\text { Myers, separate opinion of B. } \\
\text { Schwartz, para. 222). }\end{array}$ & & $\begin{array}{l}\text { U.S.-Peru FTA, Article 10.5(2) and (3). } \\
\text { U.S.-Uruguay BIT, Article 5(2) and (3). } \\
\text { U.S.-Rwanda BIT, Article 5(2) and (3). } \\
\text { U.S. Model BIT, Article 5(2) and (3). } \\
\text { Interpretive note of } 31 \text { July } 2001 \text { by the } \\
\text { NAFTA Free Trade Commission. } \\
\text { See the Glamis Gold interpretation of } \\
\text { the customary minimum standard } \\
\text { under NAFTA Article 1105, which } \\
\text { excluded from that standard the } \\
\text { concepts of free-standing legitimate } \\
\text { expectations and simple (as oppposed } \\
\text { to manifest) arbitrary treatment (Glamis } \\
\text { Gold 2009, para. 598-626). }\end{array}$ \\
\hline $\begin{array}{l}\text { Clarify that most-favored-nation } \\
\text { treatment does not extend to the } \\
\text { dispute resolution provisions of } \\
\text { other treaties. } \\
\text { Clarify that most-favored-nation } \\
\text { treatment does not invalidate the } \\
\text { specific or general exceptions in } \\
\text { NAFTA. } \\
\text { Clarify that general measures } \\
\text { adopted for a public purposes } \\
\text { may have varying effects on } \\
\text { investors and that this does not } \\
\text { violate most-favored-nation }\end{array}$ & $\begin{array}{l}\text { Sustainable } \\
\text { development - } \\
\text { appropriate policy } \\
\text { space } \\
\text { Equitable } \\
\text { governance - } \\
\text { privileging of } \\
\text { foreign investors }\end{array}$ & $\begin{array}{l}\text { Conditions access to NAFTA } \\
\text { investor-state arbitration based } \\
\text { on the terms of NAFTA rather } \\
\text { than other treaties. } \\
\text { May limit expansive } \\
\text { interpretations by tribunals of } \\
\text { the concept of discrimination } \\
\text { and its corresponding process of } \\
\text { comparative analysis. }\end{array}$ & No & $\begin{array}{l}\text { U.S.-Colombia FTA, Article 10.4(2), } \\
\text { note } 2 . \\
\text { U.S.-Peru FTA, Article 10.4(2), note } 2 . \\
\text { Canada-Peru FTA, Annex 804.1. } \\
\text { Norway draft Model BIT, Article 4(1), } \\
\text { note 3, and Article 4(3). }\end{array}$ \\
\hline
\end{tabular}




\begin{tabular}{|c|c|c|c|c|}
\hline $\begin{array}{l}\text { treatment unless the measure is } \\
\text { demonstrated to be (1) } \\
\text { intentionally discriminatory or }(2) \\
\text { discriminatory in its effects on the } \\
\text { relevant foreign investors as a } \\
\text { group. }\end{array}$ & & & & \\
\hline $\begin{array}{l}\text { Clarify that general measures } \\
\text { adopted for a public purposes } \\
\text { may have varying effects on } \\
\text { investors and that this does not } \\
\text { violate national treatment unless } \\
\text { the measure is demonstrated to be } \\
\text { (1) intentionally discriminatory or } \\
\text { (2) discriminatory in its effects on } \\
\text { foreign investors as a group. }\end{array}$ & $\begin{array}{l}\text { Sustainable } \\
\text { development - } \\
\text { appropriate policy } \\
\text { space }\end{array}$ & $\begin{array}{l}\text { May limit expansive } \\
\text { interpretations by tribunals of } \\
\text { the concept of discrimination } \\
\text { and its corresponding process of } \\
\text { comparative analysis (e.g. Pope \& } \\
\text { Talbot). }\end{array}$ & $\mathrm{No}$ & $\begin{array}{l}\text { Norway draft Model BIT, Article 3(1), } \\
\text { note } 2 . \\
\text { IISD Model International Investment } \\
\text { Agreement (2005), Article } 5(\mathrm{E}) \text {. } \\
\text { See the } A D F \text { tribunal's interpretation } \\
\text { of Article } 1102 \text {, concluding that a } \\
\text { foreign investor must provide evidence } \\
\text { of sectoral discrimination in order to } \\
\text { establish a de facto (i.e. unintentional) } \\
\text { violation of national treatment ( } A D F \text {, } \\
\text { para. } 156-157) \text {. }\end{array}$ \\
\hline
\end{tabular}




\begin{tabular}{|c|c|c|c|c|}
\hline Proposed reform & $\begin{array}{l}\text { Relevant } \\
\text { principle(s) }\end{array}$ & Comment/rationale & $\begin{array}{l}\text { Requires } \\
\text { amendment? }\end{array}$ & References \\
\hline \multicolumn{5}{|c|}{ CHECKTHE DISCRETION OF INTERNATIONAL ARBITRATORS } \\
\hline $\begin{array}{l}\text { Clarify that tribunals should defer } \\
\text { to common submissions of the } \\
\text { NAFTA governments on the } \\
\text { appropriate interpretation of the } \\
\text { treaty in specific arbitrations. }\end{array}$ & $\begin{array}{l}\text { Sustainable } \\
\text { development - } \\
\text { appropriate policy } \\
\text { space; apparent } \\
\text { pro-investor bias }\end{array}$ & $\begin{array}{l}\text { May preclude a tribunal from } \\
\text { rejecting common submissions } \\
\text { of the NAFTA governments, } \\
\text { including the investor's home } \\
\text { government, in favor of an } \\
\text { expansive pro-investor position } \\
\text { (e.g. GAMI, para. 29-30, and } \\
\text { Pope \& Talbot, para. 114). }\end{array}$ & No & NA \\
\hline $\begin{array}{l}\text { Provide expressly in NAFTA } \\
\text { Article 1131(2) that any tribunal } \\
\text { award 'must be consistent' with an } \\
\text { interpretation of NAFTA by the } \\
\text { Free Trade Commission. }\end{array}$ & $\begin{array}{l}\text { Sustainable } \\
\text { development - } \\
\text { appropriate policy } \\
\text { space; apparent } \\
\text { pro-investor bias }\end{array}$ & $\begin{array}{l}\text { Removes any doubt that } \\
\text { tribunals are bound by the Free } \\
\text { Trade Commission's interpretive } \\
\text { notes, and that they may not } \\
\text { avoid such interpretations by } \\
\text { styling them as amendments. }\end{array}$ & Yes & U.S.-Chile FTA, Article 10.21(3). \\
\hline $\begin{array}{l}\text { Indicate that tribunals should } \\
\text { defer to domestic legislative and } \\
\text { judicial decisions, and policy } \\
\text { decisions of the executive, so long } \\
\text { as the decision does not target } \\
\text { foreign investors for abusive or } \\
\text { discriminatory treatment. }\end{array}$ & $\begin{array}{l}\begin{array}{l}\text { Equitable } \\
\text { governance - } \\
\text { privileging of } \\
\text { foreign investors }\end{array} \\
\text { Sustainable } \\
\text { development - } \\
\text { appropriate policy } \\
\text { space }\end{array}$ & $\begin{array}{l}\text { Encourages tribunals to defer to } \\
\text { decision-makers at the domestic } \\
\text { level in light of their superior } \\
\text { representation, independence, or } \\
\text { expertise. }\end{array}$ & No & NA \\
\hline $\begin{array}{l}\text { Clarify that the remedial authority } \\
\text { of tribunals permits them to } \\
\text { award partial damages, or simply a } \\
\text { costs award or declaratory award, } \\
\text { as adequate satisfaction for a } \\
\text { state's violation of the treaty. } \\
\text { Clarify further that a retrospective }\end{array}$ & $\begin{array}{l}\text { Sustainable } \\
\text { development - } \\
\text { appropriate policy } \\
\text { space }\end{array}$ & $\begin{array}{l}\text { Ensures that tribunals are aware } \\
\text { of their ability to tailor the } \\
\text { remedy of damages in order to } \\
\text { preserve regulatory flexibility and } \\
\text { predictability, and to reflect the } \\
\text { blameworthiness of the state in } \\
\text { the face of obligations that are } \\
\text { unclear or subject to conflicting }\end{array}$ & No & $\begin{array}{l}\text { NAFTA Article } 1135 . \\
\text { The European Court of Justice has } \\
\text { limited its Francovich doctrine of state } \\
\text { liability, by which individuals may be } \\
\text { awarded money compensation for a } \\
\text { member state's violations of EU law, } \\
\text { by requiring that the state's violation be }\end{array}$ \\
\hline
\end{tabular}




\begin{tabular}{|c|c|c|c|c|}
\hline $\begin{array}{l}\text { damages award is not appropriate } \\
\text { where a respondent state was not } \\
\text { sufficiently blameworthy. }\end{array}$ & & interpretations by past tribunals. & & $\begin{array}{l}\text { 'sufficiently serious' before damages } \\
\text { can be awarded (Brasserie du Pêcheur } \\
1996,990) .\end{array}$ \\
\hline $\begin{array}{l}\text { Clarify that the foreign investor } \\
\text { has the burden in investor-state } \\
\text { arbitration of proving (1) a } \\
\text { violation of the treaty, (2) any } \\
\text { damages it has sustained, and ( } 3 \text { ) } \\
\text { that the treaty violation was the } \\
\text { proximate cause of the damages. }\end{array}$ & $\begin{array}{l}\text { Equitable } \\
\text { governance - } \\
\text { privileging of } \\
\text { foreign investors }\end{array}$ & $\begin{array}{l}\text { May preclude unduly pro- } \\
\text { investor awards of damages by } \\
\text { tribunals. }\end{array}$ & No & $\begin{array}{l}\text { U.S.-Uruguay BIT, Protocol (section } \\
\text { 2). }\end{array}$ \\
\hline $\begin{array}{l}\text { Establish a standing process of } \\
\text { the Free Trade Commission to } \\
\text { identify areas where NAFTA } \\
\text { could be clarified periodically. }\end{array}$ & $\begin{array}{l}\text { Sustainable } \\
\text { development - } \\
\text { appropriate policy } \\
\text { space }\end{array}$ & $\begin{array}{l}\text { Enhances the coherence of the } \\
\text { regime. }\end{array}$ & & $\begin{array}{l}\text { U.S.-Chile FTA, Article } 10.13 \\
\text { (envisioning periodic review of } \\
\text { implication of the agreement). } \\
\text { Norway draft Model BIT, Article } 23 \text {. }\end{array}$ \\
\hline
\end{tabular}




\begin{tabular}{|c|c|c|c|c|}
\hline Proposed reform & $\begin{array}{l}\text { Relevant } \\
\text { principle(s) }\end{array}$ & Comment/rationale & $\begin{array}{l}\text { Requires } \\
\text { amendment? }\end{array}$ & References \\
\hline \multicolumn{5}{|c|}{ EXCEPTIONS TO PROTECT LEGITIMATE REGULATION } \\
\hline $\begin{array}{l}\text { Extend NAFTA's general } \\
\text { exceptions to its investment } \\
\text { regime. }\end{array}$ & $\begin{array}{l}\text { Sustainable } \\
\text { development - } \\
\text { appropriate policy } \\
\text { space }\end{array}$ & $\begin{array}{l}\text { Allows for regulatory measures } \\
\text { to be justified on grounds of } \\
\text { public welfare, consistent with } \\
\text { other trade and post-NAFTA } \\
\text { investment treaties. }\end{array}$ & Yes & $\begin{array}{l}\text { NAFTA Article } 2101 \text { (incorporating } \\
\text { the general exceptions under GAT'T } \\
\text { Article XX, but not extending them to } \\
\text { the investment chapter). } \\
\text { Canada Model BIT, Article 10(1). } \\
\text { Norway draft Model BIT, Article } 24 \text {. } \\
\text { IISD Model International Investment } \\
\text { Agreement (2005), Article } 25 \text {. }\end{array}$ \\
\hline $\begin{array}{l}\text { Substitute 'necessary to' for } \\
\text { 'related to' in the phrasing of } \\
\text { exceptions for environmental and } \\
\text { other measures in NAFTA Article } \\
1106(6) .\end{array}$ & $\begin{array}{l}\text { Sustainable } \\
\text { development - } \\
\text { appropriate policy } \\
\text { space }\end{array}$ & $\begin{array}{l}\text { Widens the scope of this } \\
\text { exception, consistent with post- } \\
\text { NAFTA treaties. }\end{array}$ & Yes & $\begin{array}{l}\text { CAFTA, Article 10.9(2)(c)(iii). } \\
\text { U.S.-Chile FTA, Article 10.5(3)(c)(iii). } \\
\text { U.S.-Colombia FTA, Article } \\
\text { 10.9(3)(c)(iii). } \\
\text { U.S.-Peru FTA, Article 10.9(3)(c)(iii). } \\
\text { U.S.-Uruguay BIT, Article 8(3)(c)(iii). } \\
\text { U.S.-Rwanda BIT, Article 8(3)(c)(iii). } \\
\text { U.S. Model BIT, Article 8(3)(c)(iii). }\end{array}$ \\
\hline $\begin{array}{l}\text { Revise the prohibition on } \\
\text { performance requirements to } \\
\text { permit the adoption of measures } \\
\text { that boost productivity and } \\
\text { employment. } \\
\text { Provide a specific exceptions for } \\
\text { measures that require investors to } \\
\text { use specific technology to meet } \\
\text { environmental, safety, or health } \\
\text { requirements. }\end{array}$ & $\begin{array}{l}\text { Sustainable } \\
\text { development - } \\
\text { economic } \\
\text { development in } \\
\text { the NAFTA } \\
\text { region }\end{array}$ & $\begin{array}{l}\text { Performance requirements } \\
\text { currently prohibited under } \\
\text { NAFTA Article } 1106 \text { have a } \\
\text { documented record of boosting } \\
\text { productivity and employment, } \\
\text { and should be available for } \\
\text { tailored use in this respect by } \\
\text { NAFTA governments, perhaps } \\
\text { supervised by a regional } \\
\text { investment commission. }\end{array}$ & Yes & $\begin{array}{l}\text { Norway draft Model BIT, Article 7(2). } \\
\text { IISD Model International Investment } \\
\text { Agreement (2005), Article } 12 .\end{array}$ \\
\hline Establish a general exception for & Sustainable & Allows greater predictability and & Yes & U.S.-Uruguay BIT, Article 20(2)(a); \\
\hline
\end{tabular}


prudential measures, including measures related to ensuring the integrity and stability of the

financial system. adoption of financial measures, during which no claim can be brought and no compensation entitlement arises for foreign investors.

Establish a general exception for non-discriminatory measures that are adopted in good faith to limit cross-border transfers of capital where aimed at ensuring the safety, soundness, and integrity of financial institutions.

Clarify that the exception in NAFTA Article 1109(4) for good faith application of laws relating to dealing in 'securities' also includes dealing in 'futures, options, or derivatives'.

Allow an exception to the obligation to permit capital transfers in NAFTA Article 1109(1) for measures concerning financial security or concerning

\begin{tabular}{|c|c|c|c|}
\hline $\begin{array}{l}\text { development - } \\
\text { stability of the } \\
\text { financial system }\end{array}$ & flexibility in financial regulation. & & $\begin{array}{l}\text { U.S. Model BIT, Article 20(2)(a). } \\
\text { Canada Model BIT, Article 10(2) and } \\
\text { (3). } \\
\text { Norway draft Model BIT, Article } 25 . \\
\text { IISD Model International Investment } \\
\text { Agreement (2005), Article 51(B). }\end{array}$ \\
\hline $\begin{array}{l}\text { Sustainable } \\
\text { development - } \\
\text { stability of the } \\
\text { financial system }\end{array}$ & $\begin{array}{l}\text { Ensures regulatory flexibility in } \\
\text { the face of a financial crisis. } \\
\text { Protects the ability of regulators } \\
\text { to safeguard the financial system. }\end{array}$ & Yes & $\begin{array}{l}\text { U.S.-Chile FTA, Annex 10-C(1)(e). } \\
\text { Canada-Colombia FTA, Annex } 810 . \\
\text { Canada Model BIT, Article 14(6). }\end{array}$ \\
\hline $\begin{array}{l}\text { Sustainable } \\
\text { development - } \\
\text { stability of the } \\
\text { financial system }\end{array}$ & $\begin{array}{l}\text { Precludes an unduly anti- } \\
\text { regulation interpretation of the } \\
\text { term 'securities' by tribunals, and } \\
\text { is consistent with post-NAFTA } \\
\text { reforms. }\end{array}$ & No & $\begin{array}{l}\text { CAFTA, Article 10.8(4)(b). } \\
\text { U.S.-Chile FTA, Article 10.8(5)(b). } \\
\text { U.S.-Colombia FTA, Article 10.8(4)(b). } \\
\text { U.S.-Peru FTA, Article 10.8(4)(b). } \\
\text { U.S.-Rwanda BIT, Article 7(4)(b). }\end{array}$ \\
\hline $\begin{array}{l}\text { Equitable } \\
\text { governance - } \\
\text { privileging of } \\
\text { foreign investors }\end{array}$ & $\begin{array}{l}\text { Allows a government to hold a } \\
\text { foreign investor responsible for } \\
\text { its duties and obligations by } \\
\text { restricting capital transfers in } \\
\text { response to specific damage it }\end{array}$ & Yes & $\begin{array}{l}\text { Norway draft Model BIT, Article } \\
9(3)(\text { ii)(d). }\end{array}$ \\
\hline
\end{tabular}




\begin{tabular}{|l|l|l|l|l|}
\hline $\begin{array}{l}\text { the prevention and remedying of } \\
\text { environmental damage. }\end{array}$ & has caused. & \\
\hline $\begin{array}{l}\text { Allow the respondent state to } \\
\text { raise as a defense that the claimant } \\
\text { has not complied with its duties } \\
\begin{array}{l}\text { and obligations under applicable } \\
\text { domestic or international laws. }\end{array}\end{array}$ & $\begin{array}{l}\text { Equitable } \\
\text { governance - } \\
\text { privileging of } \\
\text { foreign investors }\end{array}$ & $\begin{array}{l}\text { Enables consideration of the } \\
\text { foreign investor's duties and } \\
\text { obligations in investor-state } \\
\text { arbitrations. }\end{array}$ & Yes & $\begin{array}{l}\text { IISD Model International Investment } \\
\text { Agreement (2005), Article 18. }\end{array}$ \\
\hline
\end{tabular}




\begin{tabular}{|c|c|c|c|c|}
\hline Proposed reform & $\begin{array}{l}\text { Relevant } \\
\text { principle }(s)\end{array}$ & Comment/rationale & $\begin{array}{l}\text { Requires } \\
\text { amendment? }\end{array}$ & References \\
\hline \multicolumn{5}{|c|}{ REVISE THE STATEMENT OF OBJECTIVES } \\
\hline $\begin{array}{l}\text { Revise the statement of objectives } \\
\text { of NAFTA and of the investor- } \\
\text { state regime to refer to - for } \\
\text { example - the importance of } \\
\text { policy space and regulatory } \\
\text { flexibility, corporate social } \\
\text { responsibility, and equitable } \\
\text { governance of investment } \\
\text { disputes based on judicial } \\
\text { openness and independence. }\end{array}$ & $\begin{array}{l}\text { Sustainable } \\
\text { development - } \\
\text { appropriate policy } \\
\text { space } \\
\text { Equitable } \\
\text { governance - } \\
\text { adjudicative } \\
\text { independence and } \\
\text { impartiality }\end{array}$ & $\begin{array}{l}\text { The treaty's objectives should } \\
\text { refer to public welfare aims } \\
\text { alongside those of increased } \\
\text { investment. Tribunals have relied } \\
\text { on the current statement of } \\
\text { objectives to support unduly } \\
\text { pro-investor interpretations of } \\
\text { Chapter } 11 \text { (e.g. Metalclad). }\end{array}$ & Yes & $\begin{array}{l}\text { NAFTA, Articles 102(1)(c) and } 1115 . \\
\text { U.S.-Colombia FTA, Section B } \\
\text { (omitting any statement of objectives } \\
\text { regarding investor-state dispute } \\
\text { settlement). } \\
\text { Canada-Peru FTA, Article } 810 . \\
\text { Canada-Colombia FTA, Article } 816 . \\
\text { Canada-Colombia FTA, Article } 818 \text {; } \\
\text { Canada Model BIT, Article } 20 \text { (each } \\
\text { adopting a neutral statement as to the } \\
\text { objectives of investor-state arbitration). } \\
\text { Norway draft Model BIT, preamble. } \\
\text { IISD Model International Investment } \\
\text { Agreement (2005), preamble and } \\
\text { Article } 1 .\end{array}$ \\
\hline
\end{tabular}

